\title{
PENYULUHAN PENDIDIKAN KESEHATAN PERILAKU SEKS BEBAS DI SMAN 2 KUMAI
}

\author{
${ }^{1}$ Rahaju Wiludjeng,SE.,MM \\ ${ }^{1}$ Stikes Borneo Cendekia Medika Pangkalan Bun \\ Email :ira.wiludjeng@gmail.com
}

\begin{abstract}
ABSTRAK
Seks bebas adalah hubungan seksual terhadap lawan jenis maupun sesama jenis tanpa ikatan dengan berganti-ganti pasangan. Seks bebas pada remaja dapat diartikan berbagai macam perilaku remaja yang berisiko yang terdiri dari tahapan berpegangan tangan, berkencan intim, bercumbu, sampai melakukan kontak seksual, tetapi perilaku tersebut dinilai tidak sesuai dengan norma selain itu dikarenakan remaja belum memiliki pengetahuan yang cukup tentang seksual. Pengetahuan seksual yang benar dapat memimpin remaja ke arah perilaku seksual yang rasional dan bertanggung jawab. Begitu juga sebaliknya, informasi yang salah mengakibatkan kesalahan persepsi dan menimbulkan perilaku seksual yang salah.
\end{abstract}

Kata Kunci : Pendidikan Kesehatan, Seks Bebas

\begin{abstract}
Free sex is sexual relations between the opposite sex and the same sex without bonding with multiple partners. Free sex in adolescents can be defined as various kinds of risky adolescent behaviors consisting of the stages of holding hands, intimate dating, making out, to making sexual contact, but these behaviors are considered not in accordance with norms besides that because adolescents do not have sufficient knowledge about sexuality. Correct sexual knowledge can lead adolescents towards rational and responsible sexual behavior. Vice versa, misinformation results in misperception and leads to wrong sexual behavior.
\end{abstract}

Keywords : Health Education, Free Sex 


\section{PENDAHULUAN}

Seks bebas adalah hubungan seksual terhadap lawan jenis maupun sesama jenis tanpa ikatan dengan bergantiganti pasangan (Sarwono, 2008). Menurut Irawati dalam Lubis (2013), seks bebas pada remaja dapat diartikan berbagai macam perilaku remaja yang berisiko yang terdiri dari tahapan berpegangan tangan, berkencan intim, bercumbu, sampai melakukan kontak seksual, tetapi perilaku tersebut dinilai tidak sesuai dengan norma selain itu dikarenakan remaja belum memiliki pengetahuan yang cukup tentang seksual.

Pengetahuan seksual yang benar dapat memimpin remaja ke arah perilaku seksual yang rasional dan bertanggung jawab. Begitu juga sebaliknya, informasi yang salah mengakibatkan kesalahan persepsi dan menimbulkan perilaku seksual yang salah (Kumalasari dan Andhyantoro, 2012). Pemahaman tentang seksual yang dianggap tabu oleh masyakarat dan adanya mitos-mitos yang salah tentang seksual, menyebabkan pemahaman remaja mengenai pengetahuan seksualitas masih rendah. Hal ini dibuktikan dengan tingginya angka kejadian seks bebas (Erni, 2013).

Penyakit menular seksual dan seks bebas saat ini banyak dialami oleh remaja di seluruh dunia, begitu juga dengan di Panama. Dari 592 responden, 60,8 \% sudah pernah melakukan hubungan seksual dan $24,4 \%$ positif menderita penyakit menular seksual. Penyakit menular seksual ini lebih banyak terjadi pada remaja perempuan dan terjadi dikarenakan $60 \%$ remaja yang mengaku memiliki pasangan $\geq 3$ orang dan melakukan aktivitas seksual secara rutin sebanyak 76,3\% (Amanda, et al, 2016).
Data Survei Kesehatan Reproduksi Remaja Indonesia terakhir BKKBN menyebutkan 3 sebanyak 5.912 wanita di umur 15 - 19 tahun secara nasional pernah melakukan hubungan seksual. Tidak adanya mata pelajaran khusus mengenai pendidikan seks bagi siswa juga merupakan salah satu penyebab tingginya angka kejadian seks bebas di kalangan remaja. Hal ini mungkin disebabkan masih kurangnya penyuluhan-penyuluhan yang dilakukan oleh pemerintah dan badanbadan kesehatan lainnya (Gustini, 2015).

Berdasarkan latar belakang di atas, maka peneliti tertarik untuk mengambil judul "Penyuluhan Seks Bebasdi SMAN 2 KUMAI". Diharapkan dengan pemberian penyuluhan seks edukasi dapat meningkatkan pengetahuan remaja tentang seks bebas sehingga mencegah terjadi penyimpangan seksual pada remaja.

\section{TINJAUAN PUSTAKA}

\section{A. Definisi Perilaku Seksual}

Berikut ini adalah pengertian tentang batasan perilaku seksual, aktivitas seksual, hubungan seksual dan perilaku seksual pra nikah (Martopo, 2000):

1. Perilaku seksual adalah perilaku yang bertujuan untuk menarik perhatian lawan jenis. Perilaku seksual juga merupakan perilaku yang melibatkan sentuhan secara fisik anggota badan antara pria dan wanita yang telah mencapai pada tahap hubungan intim, biasanya dilakukan oleh pasangan suami istri.

2. Aktivitas seksual adalah kegiatan yang dilakukan untuk memenuhi dorongan seksual atau kegiatan mendapatkan kesenangan organ kelamin melalui berbagai perilaku. 
3. Hubungan seksual merupakan kontak seksual yang dilakukan berpasangan dengan lawan jenis atau sesame jenis.

4. Perilaku seks pranikah adalah perilaku seks yang dilakukan tanpa melalui proses pernikahan yang resmi menurut hokum ataupun agama dan kepercayaan masing masing individu.

5. Menurut Soetjiningsih (2004), perilaku seks pranikah pada remaja adalah segala tingkah laku remaja yang didorong oleh hasrat baik dengan lawan jenis maupun sesame jenis yang dilakukan sebelum adanya hubungan resmi sebagai suami istri. Objek seksualnya bisa berupa orang lain, orang dalam khayalan, atau diri sendiri.

Faktor yang juga diasumsikan sangat mendukung remaja untuk melakukan hubungan seksual adalah teman sebaya yang dilihat dari konformitas remaja pada kelompoknya di mana konformitas tersebut memaksa seorang remaja harus melakukan hubungan seksual. Santrock (2003) mengatakan bahwa konformitas kelompok bisa berarti kondisi di mana seseorang mengadopsi sikap atau perilaku dari orang lain dalam kelompoknya karena tekanan dari kenyataan atau kesan yang diberikan oleh kelompoknya tersebut. Apabila lingkungan peer remaja tersebut mendukung untuk dilakukan perilaku seksual, serta konformitas remaja yang juga tinggi pada peer-nya, maka remaja tersebut sangat berpeluang untuk melakukan hubungan seksual pranikah.

B. Bentuk - Bentuk Tingkah Laku Seksual
Menurut Sarwono (2007) bentuk tingkah laku seks bermacam - macam mulai dari perasaan tertarik, pacaran, kissing, kemudian sampai intercourse meliputi:

1. Kissing

Ciuman yang dilakukan untuk menimbulkan rangsangan seksual, seperti di bibir disertai dengan rabaan pada bagian - bagian sensitif yang dapat menimbulkan rangsangan seksual. Berciuman dengan bibir tertutup merupakan ciuman yang umum dilakukan. Berciuman dengan mulut dan bibir terbuka, serta menggunakan lidah itulah yang disebut french kiss. Kadang ciuman ini juga dinamakan ciuman mendalam/ soul kis

\section{Necking}

Berciuman di sekitar leher kebawah. Necking merupakan istilah yang digunakan untuk menggambarkan ciuman di sekitar leher dan pelukan yang lebih mendalam.

3. Petting

Perilaku menggesek - gesekkan bagian tubuh yang sensitif, seperti payudara dan organ kelamin. Merupakan langkah yang lebih mendalam dari necking. Ini termasuk merasakan dan mengusap - usap tubuh pasangan termasuk lengan, dada, buah dada, kaki, dan kadang kadang daerah kemaluan, baik di dalam atau di luar pakaian.

4. Intercrouse

Bersatunya dua orang secara seksual yang dilakukan oleh pasangan pria dan wanita yang ditandai dengan penis pria yang ereksi masuk kedalam vagina untuk mendapatkan kepuasan seksual. 
Hubungan seksual yang dilakukan pada remaja, terutama remaja putrid akan dapat menyebabkan kehamilan pada usia belasan tahun akan mengkibatkan resiko resiko tertentu baik bagi ibu atau janin yang dikandungnya. Selain itu, pada kehamilan remaja yang tidak dikehendaki dapat disertai oleh akibat medis dan psikologis. Misalnya terjadinya abortus, tidak bias menyelesaikan pendidikan sekolah, penyiksaan anak atau ketidakpedulian dan bunuh diri. Remaja putri yang berusia 15-19 tahun mempunyai kemungkinan 2 kali lebih besar meninggal dunia saat mereka hamil atau melahirkan dibandingkan dengan perempuan berusia 20 tahun ke atas. Sementara itu remaja yang berusia di bawah 14 tahun, mempunyai kemungkinan meninggal 5 kali lebih besar. Kehamilan pada remaja yang berusia kurang dari 14 tahun memiliki risiko komplikasi medis lebih besar daripada perempuan dengan usia yang lebih dewasa. Hal ini dikarenakan bahwa panggul pada perempuan belum berkembang dengan sempurna. Pada remaja putri, dua tahun setelah menstruasi yang pertama seorang perempuan masih mungkin mencapai pertumbuhan panggul antara 2-9\% dan tinggi badan $1 \%$, sehingga perempuan yang melahirkan kurang dari 14 tahun banyak mengalami disproporsi kepala bayi dan panggul ibu atau disproporsi sefalo pelvik.

C. Faktor-Faktor yang Memengaruhi Perilaku Seksual Remaja

San trock (2007) yang mengutip Bandura menyatakan bahwa faktor pribadi /kognitif, faktor perilaku dan faktor lingkungan dapat berintraksi secara timbalbalik. Dengan demikian dalam pandangan Bandura, lingkungan dapat memengaruhi perilaku seseorang, namun seseorang dapat bertindak untuk mengubah lingkungan.

Menurut Suryoputro dkk (2007), faktor yang berpengaruh pada perilaku seksual antara lain adalah faktor personal termasuk variabel seperti pengetahuan, sikap seksual dan gender, kerentanan terhadap risiko kesehatan reproduksi, gaya hidup, harga diri, lokus kontrol, kegiatan sosial, self efficacy dan variabel demografi (seperti: umur pubertas, jenis kelamin, status religiusitas, suku dan perkawinan). Faktor lingkungan termasuk variabel seperti akses dan kontak dengan sumber, dukungan dan informasi, sosial budaya, nilai dan norma sebagai dukungan sosial.

\section{MATERI DAN METODE PELAKSANAAN}

\section{A. Khalayak Sasaran}

Khalayak sasaran pengabdian masyarakat ini adalah siswa SMAN 2 KUMAI, namun setelah disosialisasikan peserta diharapkan menerapkannya dilingkungan sekitar dan membagi ilmunya dengan yang lain. Namun demikian kegiatan pendidikan kesehatan perilaku seks bebas dilaksanakan sesuai dengan rencana awal dan kepada para peserta pelatihan diberikan materi pendidikan kesehatan perilaku seks bebas.

\section{B. Metode Kegiatan}

Untuk memecahkan permasalahan yang dihadapi dalam pelatihan ini, maka dipilih beberapa metode pemecahan sebagai berikut : 
1. Metode tanya jawab dan ceramah,digunakan pada saat pemberian pendidikan kesehatan perilaku seks bebas.

2. Metode demonstrasi dan latihan, digunakan pada saat menyampaikan materi konseling.

3. Evaluasi hasil praktik konseling menggunakan pedoman evaluasi yang sudah disiapkan sebelumnya.

\section{HASIL DAN PEMBAHASAN}

\section{A. Hasil}

Hasil kegiatan pengabdian pada masyarakat ini dapat disimpulkan baik. Hal ini dibuktikan dari hasil praktik peserta. Berdasarkan hasil evaluasi praktik, para peserta dapat melakukan konseling dengan baik. Evaluasi hasil praktek meliputi :

1. Banyaknya yang bertanya,

2. Hasil pre dan post test

3. Pemecahan masalah dalam menyelesaikan sebuah kasus

\section{B. Pembahasan}

Pada pelatihan ini melakukan pendidikan kesehatan reproduksi yang diaplikasikan dalam bentuk konseling teman sebaya. Hal ini dilakukan dengan tujuan mengetahui kemampuan para peserta melakukan konseling sebagai bentuk evaluasi di lakukan semua peserta untuk mengukur kemampuan sebelumnya belum pernah dipraktikan sama sekali. Berdasarkan evaluasi hasil praktik untuk pendidikan kesehatan reproduksi diperoleh hasilsebagai berikut:

1. Banyaknya yang bertanya, setelah pembicara selesai menyampaikan materi dan dibuka sesi pertanyaan hampir dari $50 \%$ peserta ingin bertanyaan, ini menunjukkan bahwa antusias siswa sangat tinggi.

2. Hasil pre dan post test,setelah dilakukan pre dan post test maka didapatkan hasil yang menunjukkan bahwa ada peningkatan pengetahuan.

3. Pemecahan masalah dalam menyelesaikan sebuah kasus. Setelah sesi penyampaian materi selesai maka dilanjutkan yang namanya sesi konseling sebaya yang dimana dirancang seperti drama dan diberi beberapa kasus.

4. Hasil Akhir dari kegiatan ini siswa dapat melakukan konseling kepada teman sebaya dengan melakukan berbagai macam pendekata yang sudah didapat dari materi khususnya yang berhubungan dengan kesehatan perilaku seks bebas.

\section{SIMPULAN DAN SARAN}

\section{A. Simpulan}

$\begin{array}{lr}\text { Kegiatan } & \text { pengabdian } \\ \text { kepada masyarakat yang telah } \\ \text { dilakukan ini banyak memberikan } \\ \text { manfaat terutama dalam } \\ \text { meningkatkan pengetahuan, sikap, } \\ \text { serta keterampilan dalam } \\ \text { melakukan konseling kepada } \\ \text { sebaya. Selain itu kegiatan } \\ \text { pengabdian kepada masyarakat ini } \\ \text { dapat dijadikan sebagai sarana } \\ \text { untuk meningkatkan keterampilan, } \\ \text { pengembangan kreativitas, dan } \\ \text { menambah wawasan serta }\end{array}$


pengetahuan tentang kesehatan perilaku seks bebas serta kemampuan dalam melakukan konseling sebaya. Konseling sebaya diyakini dapat menjadi salah satu cara mengatasi masalah remaja yang kompleks.

B. Saran

Setelah pelatihan berakhir diharapkan peserta yang telah memperoleh pengetahuan kesehatan perilaku seks bebas dan keterampilan konseling sebaya dapat mentransfer pengetahuan dan mempraktekkan ilmu yang sudah didapat sehingga bermanfaat buat teman sebaya.

\section{DAFTAR PUSTAKA}

Bungin, M. Burhan. (2008). Pornomedia : sosiologi media, konstruksi social teknologi telematika \& perayaan seks di media massa. Jakarta :

Kencana Desmita. (2009). Psikologi perkembangan. Bandung : PT Remaja Posdakarya

Dianawati,A. (2003). Pendidikan seks untuk remaja. Jakarta : kawan pustaka Emka,M. (2003). Jakarta Undercover, Sex n The City. Jakarta: Galang Press 